\title{
Proteomics in Biomarker Discovery and Drug Development
}

\author{
Qing-Yu He ${ }^{1,2}$ and Jen-Fu Chiu ${ }^{2,3}$ \\ ${ }^{1}$ Department of Chemistry, ${ }^{2}$ Open Laboratory of Chemical Biology of the Institute of \\ Molecular Technology for Drug Discovery and Synthesis, ${ }^{3}$ Institute of Molecular Biology, \\ University of Hong Kong, Hong Kong, China
}

Running title: Proteomics in Biomarker Discovery and Drug Development

Correspondence to: Dr. Qing-Yu He, Department of Chemistry, University of Hong Kong, Pokfulam, Hong Kong, China. Tel: (852)2299-0787, Fax: (852)2817-1006, E-mail: qyhe@hku.hk

\section{List of Abbreviations:}

2-DE, 2-dimensional gel electrophoresis; $\mathrm{p}$, isoelectric point; MS, mass spectrometry; MALDI-TOF, matrix-assisted laser desorption ionization time of flight; SELDI, surface enhanced laser desorption ionization; ESI MS/MS, electrospray ionization tandem MS; LC, liquid chromatography; ICAT, isotope-coded affinity tags; TCC, transitional cell carcinoma; SCC, squamous cell carcinoma; PSA, prostate-specific antigen; HCC, hepatocellular carcinoma; LCM, laser capture microdissection; DIGE, differential in-gel electrophoresis; RA, rheumatoid arthritis; HBV/HCV, hepatitis B or C virus; PPs, Peroxisome proliferators.

Grant sponsor: Hong Kong Research Grants Council Grants HKU 7227/02M (to Q.Y.H.) and HKU 7218/02M (to J.F.C.), and University Grant 10204007 (to Q.Y.H.), the Department of Chemistry, and the Areas of Excellence scheme of Hong Kong University Grants Committee. 


\section{Abstract}

Proteomics is a research field aiming to characterize molecular and cellular dynamics in protein expression and function on a global level. The introduction of proteomics has been greatly broadening our view and accelerating our path in various medical researches. The most significant advantage of proteomics is its ability to examine a whole proteome or subproteome in a single experiment so that the protein alterations corresponding to a pathological or biochemical condition at a given time can be considered in an integrated way. Proteomic technology has been extensively used to tackle a wide variety of medical subjects including biomarker discovery and drug development. By complement with other new technique advances in genomics and bioinformatics, proteomics has a great potential to make considerable contribution to biomarker identification and to revolutionize drug development process. This article provides a brief overview of the proteomic technologies and their application in biomarker discovery and drug development.

Keywords: proteomics, biomarker, drug discovery, proteomic application 


\section{INTRODUCTION}

The rapid progresses in genomics and spectacular advances in mass spectroscopic technology in last several years have led us into a new field, proteomics. Today, proteomics has been growing to be a revolutionary tool in various studies in molecular medicine including biomarker discovery and drug development. Disease involves alterations in protein expression and thus offers a basis for detection of biomarkers and drug targets through examining the protein expression profiles with proteomics. By directly analyzing proteins in body fluids including serum, spinal fluid, urine and exhaled breath, proteomics can globally identify and monitor biomarkers and thus change the way we diagnose, treat and prevent disease. By comprehensively inspecting the entire proteome in given tissues or cells treated with drug or drug candidates, proteomics provides a detailed map of protein interactions related to disease-associated pathways thus facilitate drug development. In this review article, we aim to briefly summarize the technology of proteomics and its application in biomarker discovery and drug development.

\section{Definition of Proteomics}

Proteome refers to the entire protein complement expressed by a genome and proteomics is the study of the proteome [Wasinger et al., 1995; Wilkins et al., 1996]. Since the proteome is dynamic, proteomics can be defined as a research field that involves the large-scale identification, characterization and quantitation of proteins expressed in a cell line, tissue or organism under given conditions. Proteomocs is a powerful approach that integrates recent technological advances in high-throughput protein separation, mass spectrometry, genomic database and bioinformatics to address important physiological and medical questions. 


\section{Protein Expression and Modification}

Proteins, not genes, are functional molecules in cells and represent important targets for the therapeutic intervention. It is impossible to accurately predict genes and their structures by genomic data and bioinformatics. Only through the study of proteins can the existence of a particular gene be confirmed and the function of the protein expressed by the gene be characterized. Moreover, protein expression and the expression level are not the direct reflection of the mRNA levels in cells and protein expression also subjects to posttranslational modification that exists in hundreds different types. As a result, a gene could express different types of proteins with different amounts under different conditions. These varied phenotypes are responsible for the actual biological functions of a gene in cells. Proteomics is established to address these problems. The applications of proteomics include the study of protein expression and modification under a given biological condition, the characterization of protein functions in a genome, the identification of protein localization and compartmentalization at a given time, and the determination of protein-protein interactions related to a biological process. In this regard, proteomics can be classified into three main types, expression proteomics, functional proteomics and structural proteomics [Graves and Haystead 2002].

\section{Expression proteomics}

Expression proteomics looks at the different display of proteins expressed in a given tissue, body fluid or cell and thus searches for biomarkers and/or drug targets. In this approach, entire protein extracts are separated to generate protein profiles. By comparing the protein profiles between a health or control sample and a diseased or drug-treated sample, proteins altered in their expression levels and patterns (e.g. modification) are identified. Further characterization can determine if these proteins are disease-specific or drugassociated targets. 


\section{Functional proteomics}

Functional proteomics focuses on a group of proteins assembling a specific biological function and studies their protein-protein or protein-DNA/RNA interactions and posttranslational modifications. Specific types of proteins or sub-proteomes are isolated through affinity chromatography or other chemical method and then subjected to further proteomics analysis based on how these proteins in the biological system interact with each other, in pairs or in protein complexes, within complicated cellular pathways. This approach allows a selected group of proteins to be characterized in response to internal or external signals and thus provides information about protein signaling, disease pathogenesis and protein-drug interactions.

\section{Structural proteomics}

Structural proteomics aims at mapping out the structures of all the proteins or protein complexes in a specific cellular organelle and building up the relationships of these proteins in a global view. This type of approach attempts to characterize all the proteins in a genome and integrate their protein-protein interactions into a "proteomics map" with "functional, structural and location annotation”. One can also isolate or pre-fragment the proteins or protein complexes from specific organelles and then analyze their locations and their relations with other proteins which make up the functional characteristics of these organelles.

\section{TECHNOLOGY PLATFORMS OF PROTEOMICS}

There are several proteomic platforms available at the moment. A typical workflow of a platform generally consists of, in subsequence, sample preparation or extraction, protein separation or pre-fractionation, comparative profiling of protein expressions, proteolytic digestion and mass analysis, protein identification through database matching or protein 
sequencing, and finally protein validation and biochemical characterization. The commonly used proteomic techniques are briefly introduced as follows.

\section{2-D gel electrophoresis}

The first and most commonly used technique in proteomics is 2-dimensional gel electrophoresis (2-DE). In 2-DE, proteins are extracted from cells or tissues and then separated according to their isoelectric points (pIs) in the first dimension and their molecular weights in the second dimension to generate protein profiles. 2-DE has a powerful resolution of separating thousands of proteins in a single gel, a capacity that no other method can overpass in protein separation up today. After 2-DE separation, proteins in gels can be visualized by Coomasie blue or silver staining and gel images are digitalized and analyzed with a computer-aid special software. Interesting (altered) protein spots are identified, cut off and subjected to in-gel tryptic digestion. The resulting peptide mixtures are analyzed with mass spectrometry (MS) to obtain so-called peptide fingerprints which determine protein identifications through matching to genomic and proteomic databases.

2-DE is primarily used in expression proteomics in which protein profiles are compared qualitatively and quantitatively between any given sample pair. The appearance and disappearance of protein spots tell the difference of protein expression while the varied intensity of the spots reflects the different protein expression levels under a given condition. 2-DE protein profiling is especially useful in biomarker discovery in which comparison can be made between normal and diseased samples including tumor tissues and bodily fluids. 2DE also features a great strength of separating protein isoforms resulting from protein posttranslational modifications, alternative mRNA splicing and proteolytic processing due to a disease condition or drug treatment. These kinds of protein modifications and cellular processing change the molecular mass and the $\mathrm{p} I$ (charge) of proteins leading to the 
appearance of different spots in 2-D gels. This resolving ability of 2-DE has been extensively employed in the studies of functional and structural proteomics.

\section{Mass spectrometry}

After protein separation by 2-DE, MS is applied to produce mass spectra for protein identification. MS is an analytic tool to obtain protein structural information such as peptide masses, amino acid sequences, type and location of protein modification. The recently tremendous improvement of MS in sensitivity, resolution and mass accuracy made this analytic tool a core technology in proteomics. Before MS analysis, proteins are subjected to "in-gel” digestion with a protease and the proteolytic peptides are extracted from the gels. When applied to MS, protein peptides are ionized with a "soft" ion source, and the ionized peptide mixture is resolved in a mass analyzer based on the mass/charge $(\mathrm{m} / \mathrm{z})$ ratio of the peptides, which are then detected in sequence by a detector and are finally displayed from low to higher mass as a mass spectrum.

The most widely used MS is matrix-assisted laser desorption ionization time of flight mass spectrometry (MALDI-TOF MS) [Yates 1996; Yates, III 1998]. With MALDI-TOF, digested peptides are mixed with a chemical matrix that can absorb energy from light, and the mixture is co-crystallized in spots on a sample plate. When a laser beam fires at the spots, the matrix absorbs energy and transfers it to the peptides which "flight” in gas phase by picking up a proton and thus being charged. These ionized spices are then resolved by their different flight time in a high-vacuum tube to reach the detector. For most proteins, 10 ng (200 fmol for a $50-\mathrm{kD}$ protein) can be reliably detected by MALDI-TOF. MALDI-TOF is principally used in peptide mass fingerprinting and is a primary instrument in large-scale proteomics because it can be integrated into a high-throughput automatic workflow of proteomics.

Another frequently used MS in proteomics is nano electrospray ionization tandem MS (ESI MS/MS) [Yates, III et al., 1997; Yates, III et al., 1999]. In ESI MS/MS, a microcapillary 
tube containing $1 \mu \mathrm{l}$ of peptide solution sprays a fine mist of charged droplets generated from a potential difference between the capillary and the inlet to the mass spectrometer. Desolvated peptide ions are formed as the solvent evaporated in a high vacuum chamber, and are resolved to produce the first MS scan. From the MS scan, a peptide ion (parent ion) is selectively transmitted into a collision chamber where the peptide is fragmented by interactions with an inert gas. The fragments of the peptide ion are then resolved based on their $\mathrm{m} / \mathrm{z}$ ratio to generate the second MS spectrum with a series of small peptides that differ by only a single amino acid. By combining these small peptides together, the amino acid sequence of the parent peptide can be constructed.

In routine proteomics, proteins in question are generally analyzed firstly with MALDI-TOF MS through peptide fingerprinting. If proteins cannot be identified by fingerprinting due to insufficient number of proteolytic peptides or lacking suitable DNA database for confident matching, ESI MS/MS can be used for the amino acid sequencing. These two types of MS operate in different ways and produce complementary information suitable for protein identification and thus stay in the mainstream of the technology of proteomics.

\section{SELDI-ProteinChip separation and profiling}

SELDI-ProteinChip system is a newly developed proteomics platform that uses patented technology to separate, profile and analyze proteins at the femtomole level [Jr et al., 1999; Yip and Lomas 2002]. With this approach, the surface of a protein chip is modified chemically or biochemically (Surface Enhanced) to be able to bind a certain group of proteins based on a specific physical property such as hydrophobicity, charge, etc. A small amount of crude biological sample such as serum or protein extracts is directly applied to the surface, incubated and washed. The specific proteins or functional class of proteins that match to the chemical or biochemical properties of the protein chip are retained on the surface and 
therefore separated from the protein mixture. The protein chip is then subjected to mass analysis by a ProteinChip reader (a SELDI-TOF MS) which generates mass profiles of the bound proteins in spectral or gel views. SELDI-ProteinChip system allows comparison of protein mass profiles to be made between any sample pair or among a group of samples from different biological conditions, and thus biomarkers or disease-related protein targets are identified. The great advantages of this technology include its abilities to use a very small amount of crude sample and to detect proteins with molecular weights lower than 6-kDa, which may not be observed in 2-DE in general.

\section{Protein pre-fractionation and "short-gun" approach}

Differing from the 2-DE/MALDI-TOF and SELDI-ProteinChip techniques stated above mainly focusing on protein differential expression, a new approach called "short-gun” or LC-MS/MS aims at total identification of entire proteins [McCormack et al., 1997; Peng and Gygi 2001]. This method uses reversed-phase liquid chromatography (LC) to separate the tryptic digests of entire proteins followed by on-line ESI tandem MS for peptide sequencing. In this approach, total protein extracts from cells or tissue are pre-fractioned with an anion exchange column to simplify the protein mixture. Selections of protein fractions from the column are subjected to proteolytic digestion, and the resulting digested mixture is applied to LC separation coupled online with MS/MS measurement. The generated MS spectra of whole cellular fraction are carefully analyzed and protein identification is performed through peptide assignment and database searching. This short-gun approach features less sample manipulation and total protein peptide mapping. A recent study integrating this technique with a "top-down" approach (intact protein mass analysis followed by molecular weight database search) substantially increased the dynamic range and confidence of protein identification [VerBerkmoes et al., 2002]. 


\section{ICAT modification and chemical proteomics}

As an alternative to 2-DE separation, a recently introduced method, known as isotopecoded affinity tags (ICAT) [Gygi et al., 1999], can be used for protein expression profiling. This technique depends on the chemical labeling of any pair of protein samples with two identical reagents isotopically different in mass, allowing the relative amount of protein to be quantitatively compared in the subsequent mass spectral determination. With ICAT modification, the pair of protein samples are labeled on their cystine residues respectively with either light or heavy form of ICAT chemical reagents and then mixed together for proteolytic digestion. The digested peptide mixture is further purified through avidin affinity chromatography by means of the biotin tag on ICAT reagents to isolate the ICAT-labeled peptides. MS analysis of these peptides produces the peak ratios for different protein expression and subsequent MS/MS peptide sequencing results in identification of proteins in altered expression levels.

Similar strategies using specific protein-modifying reagents (tags) in facilitating expression profiling and functional studies of distinct protein families within a complex

proteome is now classified as chemical proteomics [Jeffery and Bogyo 2003]. These modifying reagents are designed and synthesized to be able to selectively react with distinct protein residues or protein families mechanistically or functionally. The modified proteins can be purified or isolated based on their tag properties and then the targeted proteins can be identified and/or further characterized with MS. Chemical proteomics has great potential in accelerating the studies of target identification and validation and drug discovery.

\section{APPLICATION OF PROTEOMICS IN BIOMARKER DISCOVERY}

Biomarkers are usually disease-associated proteins that can be detected and quantitatively measured for disease diagnosis, staging, prognosis and treatment monitoring. 
The development of a disease condition is a multi-step process involving different biological pathways. Many proteins are altered in expression levels and/or expression types such as modification during this process. These altered proteins can be detected in tissue, blood, urine or other body fluids and thus provide indicators for the disease. An ideal biomarker should have high specificity for a certain disease condition; this kind of biomarkers is rare, however. Most of biomarkers are those proteins expressed by many different types of diseases but with variant expression levels from type to type. Combining several unspecific biomarkers together may lead to a specific index for a particular disease. In this regard, proteomics offers suitable and powerful technique platforms for the biomarker discovery, characterization and evaluation because of its capacity of globally examining the protein expression profiles under given conditions. Actually, since they were introduced, proteomics approaches, especially 2DE/MALDI-TOF and SELDI/ProteinChip, have been extensively used to identify biomarkers for various diseases.

\section{Cancer}

Cancer is a prime target to study by proteomics. Lung cancer is one of most comprehensively studied malignancies using proteomics techniques. Substantial effort was made by Hanash and co-workers, together with other researchers, to identify tumorassociated proteins as novel biomarkers for the early diagnosis and/or as new targets for therapeutic treatment [Hanash et al., 2001; Hanash 2001; Naour et al., 2002; Wang and Hanash 2002]. A number of potential tumor markers have been found in tissue, sera or tumor cells by using comparative 2DE technique coupled with MS and microarray analysis or autoantibodies blotting [Brichory et al., 2001a; Brichory et al., 2001b; Chang et al., 2001; Chen et al., 2002a; Madoz-Gurpide et al., 2001]. Especially, cytokeratin isoforms were demonstrated to correlate with patient survival in the cancer [Gharib et al., 2002] and the over-expression of oncoprotein 18 was found to reflect the poor differentiation status in lung 
carcinoma [Chen et al., 2003]. A database integrated protein expression with mRNA levels in lung cancer has also been constructed to facilitate biomarker discovery and tumor classification [Oh et al., 2001]. To study the arsenic-induced cell transformation of lung cancer, we have performed a proteomic analysis by using SELDI-TOF ProteinChip technology [He et al., 2003a]. Differential protein profiles between control and arsenicinduced transformed lung cells distinguished several prominent protein peaks, indicating the potential of SELDI proteomics for identifying biomarkers for lung cancer [He et al., 2003a].

Another cancer that received extensive proteomics analysis is bladder tumor, including transitional cell carcinoma (TCC), squamous cell carcinoma (SCC) and adenocarcinoma. Celis research group has long been involved in the searching for biomarkers that may form the basis for diagnosis, prognosis and treatment of bladder cancer using proteome expression profiling [Celis et al., 1999d; Celis et al., 2000; Celis and Gromov 2003]. They have systematically analyzed hundreds of fresh tumors, random biopsies, cystectomies and urines using proteomics and immunohistochemical analysis to establish comprehensive 2-DE databases of bladder cancer for tumor marker and protein target discovery [Celis et al., 1999c; Rasmussen et al., 1996]. Their studies also led to the identification of several protein markers associated with TCC progression [Celis et al., 1996; Gromova et al., 1998] and SCC differentiation [Celis et al., 1999b; Ostergaard et al., 1997] and invasion [Celis et al., 1999a; Ostergaard et al., 1999]. In addition, ProteinChip technology has also been utilized to screen urine samples from TCC patients and five potential novel TCC biomarkers have been found through the study [Vlahou et al., 2001].

Many investigators have also concentrated on the identification of biomarkers for breast cancer [Hondermarck et al., 2001; Luftner and Possinger 2002; Wulfkuhle et al., 2001]. Again, 2DE protein profiling was used as a major approach to search for tumor-related proteins in tumor tissues [Franzen et al., 1996; Wulfkuhle et al., 2002] and breast tumor cells 
[Adam et al., 2003; Le Naour et al., 2001], while SELDI-ProteinChip was a sensitive tool to detect new biomarkers in serum [Li et al., 2002] and nipple aspiration fluid [Cho et al., 2002; Paweletz et al., 2001b]. In the unique case of breast cancer, the biomarker discovery in nipple aspirate fluid features an even special significance as it may lead to a potential non-invasive method in the diagnosis of the disease. A recent elegant experiment used bilateral matched pair breast ductal fluids from women with unilateral invasive breast carcinoma as specimens to examine protein expressions distinct between the breast pair with 2DE proteomics [Kuerer et al., 2002]. This study has identified several differently expressed proteins that are associated with breast carcinoma and may be potential biomarkers with a clinical role.

Since the current clinical biomarker, prostate-specific antigen (PSA), lacks the specificity and sensitivity in the diagnosis of prostate cancer, efforts were made to analyze multiple proteins as signature proteomic patterns for distinguishing cancer from noncancer and thus as an index of biomarkers for accurate detection of prostate cancer [Adam et al., 2002a; Petricoin, III et al., 2002; Qu et al., 2002]. Researchers also looked for alternatives of PSA by examining the proteomic alternations of PSA-antichymotrypsin complex [Qian et al., 1997], low-MW PSA [Charrier et al., 2001], and other tumor-associated proteins such as nuclear matrix proteins [Alberti et al., 2000; Lakshmanan et al., 1998]. In particular, improvements in sensitivity and accuracy have been obtained by applying laser capture microdissection (LCM) to accumulate tumor cells from tissue samples prior to SELDI/ProteinChip [Jr et al., 1999; Wellmann et al., 2002] or 2DE/MALDI [Ahram et al., 2002; Ornstein et al., 2000; Paweletz et al., 2001a] proteomic analysis. These studies have resulted in identification of a number of unique proteins that are associated with the actual molecular events in carcinogenesis and may be potential candidates for new specific biomarkers. 
Lacking specific biomarkers in clinical assessment is also the problem for hepatocellular carcinoma (HCC). Attempts have been taken to discover novel biomarkers for HCC early detection by means of proteomics [Seow et al., 2001; Shalhoub et al., 2001; Steel et al., 2001]. These include the identification of two HCC specific nuclear matrix proteins [Chew et al., 1997], novel protein Hcc-1 [Choong et al., 2001], a distinct repertoire of autoantibodies in HCC [Le Naour et al., 2002], aldehyde dehydrogenase variants [Park et al., 2002] and sarcosine dehydrogenase, liver carboxylesterase, peptidyl-prolyl isomerase A and lamin B1 [Lim et al., 2002]. In addition, proteome databases have been also established to aid in pathological staging, protein profiling and biomarker discovering of HCC [Cho et al., 2002; Liang et al., 2002; Seow et al., 2000].

Gastric and colon cancers are two common malignant tumors in digestive tract. Both diseases are traditionally identified and classified by histological criteria due to no specific and suitable biomarkers currently available for clinical assessment. However, only a limit number of proteomic studies involved in the direct discovery of biomarkers for these cancers, although proteome databases of tissue [Cole et al., 2000; Ha et al., 2002] and cell lines [Hoffmann et al., 2001; Simpson et al., 2000; Tomlinson et al., 2002] have been constructed. So far, attentions have been attracted to identify specific proteins or antigens that reflect the chemo- and thermo-resistant properties of stomach cancer [Sinha et al., 1998; Sinha et al., 2001] and that are associated with Helicobacter pylori, the human pathogen that causes an inflammatory process leading to gastric cancer [Chang et al., 1999; Enroth et al., 2000; Haas et al., 2002]. For colon cancer, a few candidate proteins have been found in tissue samples to be potential markers for correlating to malignant transformation and tumor metastasis [Brunagel et al., 2002; Chaurand et al., 2001a; Chaurand et al., 2001b; Keesee et al., 1994; Stulik et al., 2001]. 
Other cancers that received proteomic analysis for biomarker or antigen identification include ovarian cancer [Ardekani et al., 2002; Bandera et al., 2003; Liotta et al., 2003], renal cell carcinoma [Balabanov et al., 2001; Klade et al., 2001; Sarto et al., 1999], head and neck cancer [Patel et al., 2001; Srisomsap et al., 2002; Zhou et al., 2002], neuroblastoma [Prasannan et al., 2000] and leukemia [Hanash et al., 2002]. One recent study using 2DE to analyze LCM ovarian tumor specimens revealed several uniquely over-expressed proteins in invasive cancer, which could be important markers and/or therapeutic targets [Jones et al., 2002]. Another worth-emphasized project utilized a serological proteomic pattern generated through SELDI technology as a screening tool to classify 116 masked serum samples and yielded a sensitivity of $100 \%$ and specificity of $95 \%$ in discriminating ovarian cancer from non-cancer [Petricoin et al., 2002]. A new emerging proteomic technology, differential in-gel electrophoresis (DIGE), in combination with LCM, has also been claimed to be a powerful procedure for the molecular characterization of tumor progression and for the identification of tumor-specific biomarkers in esophageal scans cell cancer [Zhou et al., 2002].

\section{Heart disease}

Heart disease, including various cardiovascular dysfunctions, is a leading cause of death in the world. This is partially due to the lack of sensitive biomarkers for diagnosis and the limited option of therapeutic treatments. Although the pathogenic mechanisms of cardiovascular diseases remind largely unknown, it can be speculated that extensive alternations of myocardial proteins accompany the disease processes and determine the progression and prognosis. Researchers in this area promptly realized that proteomics is a robust tool to globally characterize these underlying protein changes for better understanding of the basis of heart disease and for identification of novel target proteins for diagnosis and therapy [Arrell et al., 2001b; Dunn 2000; Jager et al., 2002; Jiang et al., 2001; Macri and Rapundalo 2001; Van Eyk 2001]. 
As the pioneering work, several proteomic databases of human, dog and rat myocardial tissues were constructed by Jungblut [Li et al., 1999; Muller et al., 1996; Otto et al., 1996], Dunn [Dunn et al., 1997; Evans et al., 1997], and Pleissner [Pleissner et al., 1996] and their colleagues. These databases contain information on several hundred identified cardiac proteins and thus build a basis for studying alternations in protein expression in models of heart disease. Recently, completed identification and characterization of bovine heart proteins was also achieved by using 2DE separation coupled with a new high-resolution MS, MALDI-TOF/TOF, which displayed both protein identify and modification on tryptophan residues [Bienvenut et al., 2002]. In addition, an Oxford team has reported the generation of a high-resolution 2DE proteomic map of platelets, a crucial factor correlated with thrombotic diseases such as stroke and myocardial infarction [O'Neill et al., 2002]. All these databases form an essential platform for cardiovascular proteomics in facilitating future identification of biomarkers and drug targets for new therapeutic strategies. Along with these database construction, to better separate the complex proteins from cardiac muscles for protein identification, various improved methods have been developed by enhancing the solubilization [Labugger et al., 2002], pre-fractioning sub-proteomes [McDonough et al., 2002; Neverova and Van Eyk 2002] and complementing separation techniques with LCMS/MS [Edmondson et al., 2002].

Based on these databases and later-on proteomic characterization, several animal models have been employed in proteomic studies for analyzing functional proteins differently expressed in various cardiovascular conditions [Arrell et al., 2001a; Heinke et al., 1998; Heinke et al., 1999; Pleissner et al., 1998; Schwertz et al., 2002; Sironi et al., 2001; Weekes et al., 1999; Weekes et al., 2003]. A number of significantly altered proteins have been identified in the ventricular tissue of bovine with delated cardiomyopathy [Weekes et al., 1999], myocardial issue of rabbits with myocardial ischemia and reperfusion injury 
[Schwertz et al., 2002] and in cardiac tissue of mice with cardiovascular complications of AIDS with chronic alcohol consumption [Weekes et al., 2003]. By compared with human expression pattern, these proteins can be further examined and determined as potential biomarkers for characterizing the heart diseases.

Similar approaches were applied to study human heart and revealed several characteristic protein markers for dilated cardiomyopathy [Corbett et al., 1998; Pleissner et al., 1997]. Researches into the discovery of autoantibodies in the sera of patients with myocarditis [Pankuweit et al., 1997], idiopathic dilated cardiomyopathy [Pohlner et al., 1997] and rheumatic heart disease [Tontsch et al., 2000] were also performed and resulted in the identification of some particular antigens including creatine kinase, dihydrolipoamide dehydrogenase, nicotinamide-adenine dinucleotide dehydrogenase and ubiquinolcytochrome-C reductase. Other studies looked at the modification and diversification of heat shock protein 27 [Scheler et al., 1997a; Scheler et al., 1999] and apolipoproteins A-I \& II [Asztalos et al., 2000; Dayal and Ertel 2002], the well-known markers for cardiac diseases, in response to different myocardial conditions. Identification and quantification of the distributing profiles of these proteins may form characteristic patterns for classifying heart diseases.

\section{Arthritis, hepatitis and others}

Proteomic technologies have also been used to study inflammatory and immune diseases. Rheumatoid arthritis (RA) is one of the autoimmune diseases that have been subjected to proteomic analysis for novel autoantigens or autoantibodies in sera as biomarkers of the disease [Hueber et al., 2002]. A sera autoantibody to a $68 \mathrm{kDa}$ antigen detected in RA synovial membranes can be a positive marker as it demonstrated a high sensitivity of $64 \%$ and specificity of $99 \%$ in distinguishing RA from non-RA and other rheumatic diseases [Blass et al., 1995], while anti-ribonucleoproteins C1/C2 present in 
systemic sclerosis and psoriatic arthritis may serve as a negative marker for their absence in RA sera [Heegaard et al., 2000]. Another potential diagnostic autoantibody, anti-alphaenolase, was identified through analyzing serum samples of 255 patients with very early arthritis, and the antibody has a specificity of $97 \%$ for RA [Saulot et al., 2002]. In addition, 2-DE technique has also been employed to detect the protein alterations in RA salivary [Beeley and Khoo 1999] and synovial fluid [Smith et al., 2001] and the potential of quantitative analysis of protein expression in forming the basis for new diagnostic methods has been discussed in these studies.

Since chronic infection with hepatitis B or C virus (HBV, HCV) is a major risk factor for the development of HCC, most proteomic studies concerning hepatitis focused on the HBV- and HCV-related HCC [Le Naour et al., 2002; Seow et al., 2001; Steel et al., 2001]. We have initiated a project using proteomic technology to globally examine HBV infected serum samples aiming at searching for serological biomarkers for the diagnosis of HBV liver inflammation, which still relies on biopsy test [He et al., 2003b]. Compared with normal and HBV-negative samples, at least seven proteins in $\mathrm{HBV}$-positive sera were found significantly changed in both expression quantity and patterns. Some of these alterations reflect the difference between low and higher stages of inflammation. We are evaluating if a combination index integrating the alterations of these proteins can be a useful biomarker for HBV diagnosis and therapy.

Biomarker discovery by proteomics for other diseases is relatively limited but promising. For example, a complementary antigen, Mtb81, has been identified and claimed to be a novel serological marker for the diagnosis of tuberculosis co-infected with human immunodeficiency virus [Hendrickson et al., 2000]. Cystatin C, detected in cerebrospinal fluid by SELDI technology, has been believed to be a biomarker for pain in humans [Mannes et al., 2003]. 


\section{APPLICATION OF PROTEOMICS IN DRUG DEVELOPMENT}

Drug-development process involves many steps, including target identification, lead selection, small-molecular screening and optimization, and clinical testing. Proteomics is a promising approach in identification of protein targets and biochemical pathways involved in disease process and thus plays an important role in drug development. By studying interrelationships between proteins that occur in health and disease, proteomics contributes insight into determination of the pathophysiological basis for target identification. By charactering the protein expression profiles following drug treatment, proteomics provides molecular information to study the mechanistic basis for drug action and toxicity. Specific biomarkers identified by proteomics may serve as protein signatures to screen drug for its efficacy, resistance and optimization. In this regard, some subdisciplines such as chemical proteomics [Jeffery and Bogyo 2003], topological proteomics [Owens 2001], clinical proteomics [Krieg et al., 2002], toxicoproteomics [Steiner and Anderson 2000] and pharmacoproteomics [Kennedy 2002; Meister 2002] have been created to recognize the special contribution of proteomics in drug discovery. It is anticipated that the increasing promise of proteomics, together with the vast genetic information provided by genomics, will rationally revolutionize the target validation and drug development process.

\section{Identification of drug targets}

Proteins constitute the majority of drug targets on which drug design processes are initiated. Proteomics is an effective means to detect the targets by globally examining the protein expression alternation and protein-protein interactions occur in disease process and/or after drug treatment. Several recent reviews summarized the application of proteomics in identification of novel drug targets for leukemias [Hanash et al., 2002], Mycobacterium tuberculosis [Betts 2002], and chronic skeletal diseases [Cho and Nuttall 2002]. Proteomic 
analyses on pathogen-host interactions in chlamydial disease [Coombes et al., 2002] and in HCV and HIV [Tang et al., 2002] were also carried out to reveal the cellular proteins that physically interact with viral proteins and thus represent potential drug targets.

A common strategy in target identification is to analyze the proteomic profiles of cells treated by a growth factor or a regulatory enzyme. By compared with untreated cells, the altered proteins in the gene network regulation or signaling pathway in response to the treatment will be identified. Examples using this method include the identification of cytokine regulated targets in human intestinal epithelial cells [Barcelo-Batllori et al., 2002], potential targets of transforming growth factor-beta in lung epithelial cells [Kanamoto et al., 2002], and cellular targets regulated by the 12-phorbol 13-myristate acetate-stimulated MKK/ERK cascade in human erytholeukemia K562 cells [Lewis et al., 2000]. A similar approach to discover the targets in signaling pathways is to focus on the phosphorylated subproteomes isolated by immunoprecipitation prior to 2-DE separation. With this approach, novel signaling proteins or potential drug targets have been detected in primary human lymphocyte treated with IFN-alpha or IL2 [Stancato and Petricoin, III 2001] and in human platelets after thrombin activation [Maguire et al., 2002].

Analyzing the proteomic profiles after treatment by a known drug is a similar strategy for the identification of new target proteins and for getting new insight into the mechanism of action for better drug design. With this method, HSP27 has been found to be a potential modulated target for antitumor drugs in breast cancer [Chen et al., 2002b], mortalin an antiapoptotic protein in vascular smooth muscle cells [Taurin et al., 2002], aldehyde dehydrogenase 1 and quinone reductase 2 selective targets of the quinolines in red blood cell purine binding proteome [Graves et al., 2002] and several cellular stress proteins to be new targets of lovastatin, a lipid lowering agent, in liver [Steiner et al., 2000]. 
Chemical proteomics is another primary approach for target identification. Chemical proteomics distills a specific group of proteins from a complex proteome by attaching chemical probes to the specific proteins which can then be studied in detail [Adam et al., 2002b; Jeffery and Bogyo 2003]. Chemical probes targeting cysteine protease have been used to identify protein targets in processes such as cellular apoptosis [Faleiro et al., 1997], cataract formation [Baruch et al., 2001] and infection with malaria parasite [Greenbaum et al., 2002]. Other activity-based chemical probes have also been used in protein profiling under a disease state or condition to detect proteins distinguishable based on their activity and affinity with the chemical tags [Adam et al., 2002c; Jessani et al., 2002; Lind et al., 2002]. Besides, new chemical probes that target serine hydrolase [Kidd et al., 2001] and phenyl sulfate [Adam et al., 2002d] and non-directed activity-based probes [Adam et al., 2001] have been synthesized. Recently, two new techniques of chemical proteomics called fluorophoreassisted light inactivation (FALI) and chromophore-assisted laser inactivation (CALI) were introduced for protein target identification and validation [Beck et al., 2002; Rubenwolf et al., 2002].

In a more systematic way, Patterson described a large-scale proteomics-based target discovery platform consisting of cell biology, chemical proteomics and bioinformatics technology [Patterson 2002]. By using isotope labeling for quantitatively analysis of protein expression and correlating with gene-specific mRNA, the differences in the expression levels of nucleic acid and proteins suggest drug targets that directly cause disease or reveal biochemical pathways that could be modulated by bioactive molecules. This system has been evaluated by applying it to study continuous cell lines derived from human pancreatic adenocarcinomas [Patterson 2002].

Other studies are based on the recognition between proteins and antibodies or specific peptides to identify the binding partners or sites with potential role in therapeutics. The 
examples include the determination of conformational immunogenic sites by proteomic mapping of patient sera with post-therapy HACA [Spencer et al., 2002] and the identification of interaction partners of a tumor suppressor peptide, p21cip1/waf1 [Gururaja et al., 2003].

\section{Action mechanism of drugs}

Numerous proteomic studies have been performed to investigate the drug mechanism of action, biochemical basis of drug activity and cellular pathways that drugs act on. The resulting data provided novel insights into drug action modes and elucidated the new modulating factors for new drug design. Differential protein expression profiling is a commonly used approach which examines the comprehensive protein alteration after drug treatment to elicit new drug-associated parameters missed by conventional method. By characterizing the altered proteins using this approach in human tumors, the drug effects and regulated pathways have been investigated in Burkitt lymphoma cells treated with drug 5'azacytidine [Poirier et al., 2001], in A549 lung adenocarcinoma cells stimulated with a synthetic cyclin-dependent kinase inhibitor [Kovarova et al., 2002], in colon cancer cells treated with butyrate [Tan et al., 2002], in acute promyelocytic leukemia cells induced by retinoic acid [Wan et al., 2001], and in renal cell carcinoma cells treated with interferongamma [Lichtenfels et al., 2002]. Other researchers addressed the drug action using animal cells, including probing for isoproterenol-stimulated signal transduction pathways in the rat C6 glioma cell [Storm and Khawaja 1999] and studying the antitumor activities of Ganoderma lucidum extracts in mouse spleen cells [Wang et al., 2002]. Animal models have also been directly utilized to study the drug mechanisms such as the inflammatory effects stimulated by interleukin and interferon in rat trigeminal ganglia [Friso et al., 2001], insulin processing mediated by insulin sensitizer drug rosiglitazone in pancreatic islets of obese mice [Sanchez et al., 2002] and the actions of 2,3,7,8-tetrachlorodibenzo-p-dioxin in rats [Bruno et al., 2002]. 
Peroxisome proliferators (PPs) are a group of chemicals that induce hepatic peroxisome proliferation, suppression of apoptosis, liver tumor formation and beta-oxidation of fatty acids. The biochemical response of PPs is mediated by PPs-activated receptor but the mechanisms underlying the mediation process and the molecular events are poorly understood. A number of investigations have been concentrated on the proteomic analysis of mouse or rat liver in response to the PPs treatment in order to delineate PPs mediated signaling pathways and their impacts on hepatocarcinogenesis [Chevalier et al., 2000; Chu et al., 2002; Edvardsson et al., 1999; Macdonald et al., 2001; White et al., 2003], and to explore the possible therapeutic value of PPs in diabetes [Edvardsson et al., 1999].

Apart from these animal studies, some bacteria have also be examined by proteomics for their response to antibiotic agents or chemical stress [Bandow et al., 2003; Bruneau et al., 2003; Duche et al., 2002; Singh et al., 2001]. 2-DE was used to profile the bacterial proteins after treatment with antibiotics and alternatives. By comparing and characterizing the protein expressions, researchers aimed at obtaining new information on the antibiotic mechanisms and classifying novel drug candidates with unknown mechanisms of action.

\section{Drug toxicity and screening}

Another topic of proteomics application in drug development is the measurement of drug toxicity, including studies on mechanistic toxicology for evaluating current drugs and on predictive toxicology for screening new drug candidates [Hellmold et al., 2002; Kennedy 2002]. Drug side-effects are common problems but the action mechanisms of the drug toxicity on human organs are largely unknown. In a typical proteomic experiment, protein extracts from a targeted organ after overdose or overtime dosing of a drug are separated by means of 2-DE or ProteinChips and the differentially expressed proteins are identified and analyzed. Further characterization of these altered proteins helps us understand the mechanism of toxicity for drug re-design and improvement, and the elicited drug-associated 
proteins can be used as predictive markers of toxicity for classifying compounds and screening large numbers of drug candidates.

Currently, most of studies have been focused on defining the mechanistic basis for hepato- and renal toxicity of various drugs such as acetaminophen [Fountoulakis et al., 2000; Ruepp et al., 2002], pyrimidine derivatives [Newsholme et al., 2000], methapyrilene, cyproterone acetate and dexamethasone [Man et al., 2002], and 4-aminophenol, D-serine and cisplatin [Bandara et al., 2003]. In many cases, specific proteins were identified and shown to correlate with molecular pathways of cellular toxicity of the drugs. Cardiovascular system is another common site that suffers drug toxicity. As demonstrated by conventional studies, cardiotoxicity could occur through various cellular and molecular mechanisms. Proteomics study on drug cardiotoxicity may present us a more comprehensive picture depicting how drug effects occur in heart and vascular system. Preliminary studies in this regard have been performed [Bandara and Kennedy 2002; Herman et al., 2001; Scheler et al., 1997b]. Attempt has also been made to utilize the specific proteins as molecular signatures for studying or evaluating other drugs [Man et al., 2002]. In addition, Randic and Basak developed a new mathematical method for characterization of effects of different toxic agents on the cellular proteome, aiming to graphically illustrate the differential protein expression between normal and drug-treated samples for understanding drug toxicity [Randic and Basak 2002]. In parallel to the drug toxicity study, the cellular mechanisms of drug resistance in some diseases such as pneumonia [Cash et al., 1999], lymphocytic leukemia [Voss et al., 2001] and myeloma [Mitsiades et al., 2003] have also been explored by employing proteomic technology.

Studies on drug toxicity may not only elucidate the mechanism of toxic damage but also detect toxin-associated proteins, which can be used as markers of toxicity for drug screening. A full drug-screening program involves the establishment of comprehensive 
databases integrated with techniques and data from genomics, proteomics and bioinformatics. For the proteomics part, these data are a combination of protein expressions of cells or organisms specifically in response to drug treatment resulting in unique expression patterns, molecular fingerprints, indicatives of drug efficacy and potential toxicity. These information will obviously accelerate the lead identification and improve the optimization of drug efficacy and safety in pre-clinical and clinical studies. One attempt to set up a proteomic program for drug screening was taken by Gianazza and co-workers [Gianazza et al., 2002], who annotated 2-DE maps of rat serum proteins under control and experimental conditions with emphasis on species-specific components and the effects of acute and chronic inflammation. Anti-inflammatory drugs were screened and tested for their efficacy and toxicity on adjuvant arthritis, the correlation between biochemical parameters and therapeutic findings from the screening proved the sensitivity of the procedure in revealing "side-effects" of the test drugs.

In a recent report, Toledo-Sherman and Chen introduced a high-throughput virtual screening platform for drug selection by integrating genomics and proteomics initiatives [Toledo-Sherman and Chen 2002]. This platform emphasized the techniques adaptable to high-throughput that can tackle multiple targets and therapeutic areas simultaneously. At the core of this program, virtual screening relies on a structure-based docking and ranking method to identify bioactive molecules in compound library database. In contrast, another new method using the free binding energy between a ligand and receptor as a scoring strategy to screen drug candidates has been proposed [Bock and Gough 2002]. A validation experiment with 2,671 samples demonstrated the effectiveness and sensitivity of the new method. Additionally, a proteomic map and database of lymphoblastoid proteins has been constructed for analyzing drug effects and lymphocyte cell diseases [Caron et al., 2002]. 


\section{CONCLUSIONS}

Proteomics is established on the basis of the tremendous technique advances in genomics, protein separation and analysis. Proteomics features a global examination of protein expressions and thus the corresponding molecular events and cellular pathway interruptions in response to a certain disease condition can be inspected in a comprehensive and integrated way. Numerous efforts and progress have been made in proteomics technology in the last few years, its application in biomarker discovery and drug development is still at its early age, however. Improvements are still needed in rising the capacity for analyzing large size of samples, refining the resolution for separating low abundant proteins and increasing the sensitivity for identifying small amounts of proteins by MS. High-throughput proteomic screening platforms integrated with genomics and bioinformatics for identifying biomarkers, drug targets and drug leads represented one of the developing directions. Explorations in pre-fractionation of sub-proteomes for better resolution and in chemical probes for higher sensitivity and specificity are also encouraging. It can be anticipated that, by complement with other new technologies, proteomics holds great potential for identifying many specific biomarkers for clinical diagnosis, large source of drug targets for therapeutic intervention, and monitoring markers of drug toxicity and efficacy for drug screening and design. 


\section{REFERENCES}

Adam BL, Qu Y, Davis JW, Ward MD, Clements MA, Cazares LH, Semmes OJ, Schellhammer PF, Yasui Y, Feng Z, Wright GL, Jr. 2002a. Serum protein fingerprinting coupled with a pattern-matching algorithm distinguishes prostate cancer from benign prostate hyperplasia and healthy men. Cancer Res 62:3609-3614.

Adam GC, Cravatt BF, Sorensen EJ. 2001. Profiling the specific reactivity of the proteome with non-directed activity-based probes. Chem Biol 8:81-95.

Adam GC, Sorensen EJ, Cravatt BF. 2002b. Chemical strategies for functional proteomics. Mol Cell Proteomics 1:781-790.

Adam GC, Sorensen EJ, Cravatt BF. 2002c. Proteomic profiling of mechanistically distinct enzyme classes using a common chemotype. Nat Biotechnol 20:805-809.

Adam GC, Sorensen EJ, Cravatt BF. 2002d. Trifunctional chemical probes for the consolidated detection and identification of enzyme activities from complex proteomes. Mol Cell Proteomics 1:828-835.

Adam PJ, Boyd R, Tyson KL, Fletcher GC, Stamps A, Hudson L, Poyser HR, Redpath N, Griffiths M, Steers G, Harris AL, Patel S, Berry J, Loader JA, Townsend RR, Daviet L, Legrain P, Parekh R, Terrett JA. 2003. Comprehensive proteomic analysis of breast cancer cell membranes reveals unique proteins with potential roles in clinical cancer. J Biol Chem 278:6482-6489.

Ahram M, Best CJ, Flaig MJ, Gillespie JW, Leiva IM, Chuaqui RF, Zhou G, Shu H, Duray PH, Linehan WM, Raffeld M, Ornstein DK, Zhao Y, Petricoin EF, III, Emmert-Buck MR. 2002. Proteomic analysis of human prostate cancer. Mol Carcinog 33:9-15.

Alberti I, Barboro P, Barbesino M, Sanna P, Pisciotta L, Parodi S, Nicolo G, Boccardo F, Galli S, Patrone E, Balbi C. 2000. Changes in the expression of cytokeratins and nuclear matrix proteins are correlated with the level of differentiation in human prostate cancer. $\mathrm{J}$ Cell Biochem 79:471-485.

Ardekani AM, Liotta LA, Petricoin EF, III. 2002. Clinical potential of proteomics in the diagnosis of ovarian cancer. Expert Rev Mol Diagn 2:312-320.

Arrell DK, Neverova I, Fraser H, Marban E, Van Eyk JE. 2001a. Proteomic analysis of pharmacologically preconditioned cardiomyocytes reveals novel phosphorylation of myosin light chain 1. Circ Res 89:480-487.

Arrell DK, Neverova I, Van Eyk JE. 2001b. Cardiovascular proteomics: evolution and potential. Circ Res 88:763-773.

Asztalos BF, Roheim PS, Milani RL, Lefevre M, McNamara JR, Horvath KV, Schaefer EJ. 2000. Distribution of ApoA-I-containing HDL subpopulations in patients with coronary heart disease. Arterioscler Thromb Vasc Biol 20:2670-2676. 
Balabanov S, Zimmermann U, Protzel C, Scharf C, Klebingat KJ, Walther R. 2001. Tumourrelated enzyme alterations in the clear cell type of human renal cell carcinoma identified by two-dimensional gel electrophoresis. Eur J Biochem 268:5977-5980.

Bandara LR, Kelly MD, Lock EA, Kennedy S. 2003. A Correlation between a Proteomic Evaluation and Conventional Measurements in the Assessment of Renal Proximal Tubular Toxicity. Toxicol Sci ..

Bandara LR, Kennedy S. 2002. Toxicoproteomics -- a new preclinical tool. Drug Discov Today 7:411-418.

Bandera CA, Ye B, Mok SC. 2003. New technologies for the identification of markers for early detection of ovarian cancer. Curr Opin Obstet Gynecol 15:51-55.

Bandow JE, Brotz H, Leichert LI, Labischinski H, Hecker M. 2003. Proteomic approach to understanding antibiotic action. Antimicrob Agents Chemother 47:948-955.

Barcelo-Batllori S, Andre M, Servis C, Levy N, Takikawa O, Michetti P, Reymond M, Felley-Bosco E. 2002. Proteomic analysis of cytokine induced proteins in human intestinal epithelial cells: implications for inflammatory bowel diseases. Proteomics 2:551-560.

Baruch A, Greenbaum D, Levy ET, Nielsen PA, Gilula NB, Kumar NM, Bogyo M. 2001. Defining a link between gap junction communication, proteolysis, and cataract formation. $\mathrm{J}$ Biol Chem 276:28999-29006.

Beck S, Sakurai T, Eustace BK, Beste G, Schier R, Rudert F, Jay DG. 2002. Fluorophoreassisted light inactivation: a high-throughput tool for direct target validation of proteins. Proteomics 2:247-255.

Beeley JA, Khoo KS. 1999. Salivary proteins in rheumatoid arthritis and Sjogren's syndrome: one-dimensional and two-dimensional electrophoretic studies. Electrophoresis 20:16521660 .

Betts JC. 2002. Transcriptomics and proteomics: tools for the identification of novel drug targets and vaccine candidates for tuberculosis. IUBMB Life 53:239-242.

Bienvenut WV, Deon C, Pasquarello C, Campbell JM, Sanchez JC, Vestal ML, Hochstrasser DF. 2002. Matrix-assisted laser desorption/ionization-tandem mass spectrometry with high resolution and sensitivity for identification and characterization of proteins. Proteomics 2:868-876.

Blass S, Specker C, Lakomek HJ, Schneider EM, Schwochau M. 1995. Novel 68 kDa autoantigen detected by rheumatoid arthritis specific antibodies. Ann Rheum Dis 54:355360.

Bock JR, Gough DA. 2002. A new method to estimate ligand-receptor energetics. Mol Cell Proteomics 1:904-910.

Brichory F, Beer D, Le Naour F, Giordano T, Hanash S. 2001a. Proteomics-based identification of protein gene product 9.5 as a tumor antigen that induces a humoral immune response in lung cancer. Cancer Res 61:7908-7912. 
Brichory FM, Misek DE, Yim AM, Krause MC, Giordano TJ, Beer DG, Hanash SM. 2001b. An immune response manifested by the common occurrence of annexins I and II autoantibodies and high circulating levels of IL-6 in lung cancer. Proc Natl Acad Sci U S A 98:9824-9829.

Brunagel G, Schoen RE, Bauer AJ, Vietmeier BN, Getzenberg RH. 2002. Nuclear matrix protein alterations associated with colon cancer metastasis to the liver. Clin Cancer Res 8:3039-3045.

Bruneau JM, Maillet I, Tagat E, Legrand R, Supatto F, Fudali C, Caer JP, Labas V, Lecaque D, Hodgson J. 2003. Drug induced proteome changes in Candida albicans: Comparison of the effect of beta(1,3) glucan synthase inhibitors and two triazoles, fluconazole and itraconazole. Proteomics 3:325-336.

Bruno ME, Borchers CH, Dial JM, Walker NJ, Hartis JE, Wetmore BA, Carl Barrett JC, Tomer KB, Merrick BA. 2002. Effects of TCDD upon IkappaB and IKK subunits localized in microsomes by proteomics. Arch Biochem Biophys 406:153-164.

Caron M, Imam-Sghiouar N, Poirier F, Le Caer JP, Labas V, Joubert-Caron R. 2002. Proteomic map and database of lymphoblastoid proteins. J Chromatogr B Analyt Technol Biomed Life Sci 771:197-209.

Cash P, Argo E, Ford L, Lawrie L, McKenzie H. 1999. A proteomic analysis of erythromycin resistance in Streptococcus pneumoniae. Electrophoresis 20:2259-2268.

Celis A, Rasmussen HH, Celis P, Basse B, Lauridsen JB, Ratz G, Hein B, Ostergaard M, Wolf H, Orntoft T, Celis JE. 1999a. Short-term culturing of low-grade superficial bladder transitional cell carcinomas leads to changes in the expression levels of several proteins involved in key cellular activities. Electrophoresis 20:355-361.

Celis JE, Celis P, Ostergaard M, Basse B, Lauridsen JB, Ratz G, Rasmussen HH, Orntoft TF, Hein B, Wolf H, Celis A. 1999b. Proteomics and immunohistochemistry define some of the steps involved in the squamous differentiation of the bladder transitional epithelium: a novel strategy for identifying metaplastic lesions. Cancer Res 59:3003-3009.

Celis JE, Gromov P. 2003. Proteomics in translational cancer research: Toward an integrated approach. Cancer Cell 3:9-15.

Celis JE, Ostergaard M, Basse B, Celis A, Lauridsen JB, Ratz GP, Andersen I, Hein B, Wolf H, Orntoft TF, Rasmussen HH. 1996. Loss of adipocyte-type fatty acid binding protein and other protein biomarkers is associated with progression of human bladder transitional cell carcinomas. Cancer Res 56:4782-4790.

Celis JE, Ostergaard M, Rasmussen HH, Gromov P, Gromova I, Varmark H, Palsdottir H, Magnusson N, Andersen I, Basse B, Lauridsen JB, Ratz G, Wolf H, Orntoft TF, Celis P, Celis A. 1999c. A comprehensive protein resource for the study of bladder cancer: http://biobase.dk/cgi-bin/celis. Electrophoresis 20:300-309.

Celis JE, Wolf H, Ostergaard M. 1999d. Proteomic strategies in bladder cancer. IUBMB Life 48:19-23. 
Celis JE, Wolf H, Ostergaard M. 2000. Bladder squamous cell carcinoma biomarkers derived from proteomics. Electrophoresis 21:2115-2121.

Chang CS, Chen LT, Yang JC, Lin JT, Chang KC, Wang JT. 1999. Isolation of a Helicobacter pylori protein, FldA, associated with mucosa-associated lymphoid tissue lymphoma of the stomach. Gastroenterology 117:82-88.

Chang JW, Jeon HB, Lee JH, Yoo JS, Chun JS, Kim JH, Yoo YJ. 2001. Augmented expression of peroxiredoxin I in lung cancer. Biochem Biophys Res Commun 289:507-512.

Charrier JP, Tournel C, Michel S, Comby S, Jolivet-Reynaud C, Passagot J, Dalbon P, Chautard D, Jolivet M. 2001. Differential diagnosis of prostate cancer and benign prostate hyperplasia using two-dimensional electrophoresis. Electrophoresis 22:1861-1866.

Chaurand P, DaGue BB, Pearsall RS, Threadgill DW, Caprioli RM. 2001b. Profiling proteins from azoxymethane-induced colon tumors at the molecular level by matrix-assisted laser desorption/ionization mass spectrometry. Proteomics 1:1320-1326.

Chaurand P, DaGue BB, Pearsall RS, Threadgill DW, Caprioli RM. 2001a. Profiling proteins from azoxymethane-induced colon tumors at the molecular level by matrix-assisted laser desorption/ionization mass spectrometry. Proteomics 1:1320-1326.

Chen G, Gharib TG, Huang CC, Thomas DG, Shedden KA, Taylor JM, Kardia SL, Misek DE, Giordano TJ, Iannettoni MD, Orringer MB, Hanash SM, Beer DG. 2002a. Proteomic analysis of lung adenocarcinoma: identification of a highly expressed set of proteins in tumors. Clin Cancer Res 8:2298-2305.

Chen G, Wang H, Gharib TG, Huang CC, Thomas DG, Shedden KA, Kuick R, Taylor JM, Kardia SL, Misek DE, Giordano TJ, Iannettoni MD, Orringer MB, Hanash SM, Beer DG. 2003. Overexpression of Oncoprotein 18 Correlates with Poor Differentiation in Lung Adenocarcinomas. Mol Cell Proteomics 2:107-116.

Chen ST, Pan TL, Tsai YC, Huang CM. 2002b. Proteomics reveals protein profile changes in doxorubicin--treated MCF-7 human breast cancer cells. Cancer Lett 181:95-107.

Chevalier S, Macdonald N, Tonge R, Rayner S, Rowlinson R, Shaw J, Young J, Davison M, Roberts RA. 2000. Proteomic analysis of differential protein expression in primary hepatocytes induced by EGF, tumour necrosis factor alpha or the peroxisome proliferator nafenopin. Eur J Biochem 267:4624-4634.

Chew EC, Liew CT, Wu S, Yang L, Yam HF, Wang SW, Lee SM, Wang ZH, Chew-Cheng SB. 1997. Electrophoretic analysis of nuclear matrix proteins in human hepatocellular carcinoma. Anticancer Res 17:3581-3585.

Cho CH, Nuttall ME. 2002. Emerging techniques for the discovery and validation of therapeutic targets for skeletal diseases. Expert Opin Ther Targets 6:679-689.

Cho SY, Park KS, Shim JE, Kwon MS, Joo KH, Lee WS, Chang J, Kim H, Chung HC, Kim HO, Paik YK. 2002. An integrated proteome database for two-dimensional electrophoresis data analysis and laboratory information management system. Proteomics 2:1104-1113. 
Choong ML, Tan LK, Lo SL, Ren E-C, Ou K, Ong S-E, Liang RCMY, Seow TK, Chung MCM. 2001. An integrated approach in the discovery and characterization of a novel nuclear protein over-expressed in liver and pancreatic tumors. FEBS Letters 496:109-116.

Chu R, Zhang W, Lim H, Yeldandi AV, Herring C, Brumfield L, Reddy JK, Davison M. 2002. Profiling of acyl-CoA oxidase-deficient and peroxisome proliferator Wy14,643treated mouse liver protein by surface-enhanced laser desorption/ionization ProteinChip Biology System. Gene Expr 10:165-177.

Cole AR, Ji H, Simpson RJ. 2000. Proteomic analysis of colonic crypts from normal, multiple intestinal neoplasia and p53-null mice: a comparison with colonic polyps. Electrophoresis 21:1772-1781.

Coombes BK, Johnson DL, Mahony JB. 2002. Strategic targeting of essential host-pathogen interactions in chlamydial disease. Curr Drug Targets Infect Disord 2:201-216.

Corbett JM, Why HJ, Wheeler CH, Richardson PJ, Archard LC, Yacoub MH, Dunn MJ. 1998. Cardiac protein abnormalities in dilated cardiomyopathy detected by two-dimensional polyacrylamide gel electrophoresis. Electrophoresis 19:2031-2042.

Dayal B, Ertel NH. 2002. ProteinChip technology: a new and facile method for the identification and measurement of high-density lipoproteins apoA-I and apoA-II and their glycosylated products in patients with diabetes and cardiovascular disease. J Proteome Res 1:375-380.

Duche O, Tremoulet F, Namane A, Labadie J. 2002. A proteomic analysis of the salt stress response of Listeria monocytogenes. FEMS Microbiol Lett 215:183-188.

Dunn MJ. 2000. Studying heart disease using the proteomic approach. Drug Discov Today 5:76-84.

Dunn MJ, Corbett JM, Wheeler CH. 1997. HSC-2DPAGE and the two-dimensional gel electrophoresis database of dog heart proteins. Electrophoresis 18:2795-2802.

Edmondson RD, Vondriska TM, Biederman KJ, Zhang J, Jones RC, Zheng Y, Allen DL, Xiu JX, Cardwell EM, Pisano MR, Ping P. 2002. Protein kinase C epsilon signaling complexes include metabolism- and transcription/translation-related proteins: complimentary separation techniques with LC/MS/MS. Mol Cell Proteomics 1:421-433.

Edvardsson U, Alexandersson M, Brockenhuus vL, Nystrom AC, Ljung B, Nilsson F, Dahllof B. 1999. A proteome analysis of livers from obese (ob/ob) mice treated with the peroxisome proliferator WY14,643. Electrophoresis 20:935-942.

Enroth H, Akerlund T, Sillen A, Engstrand L. 2000. Clustering of clinical strains of Helicobacter pylori analyzed by two-dimensional gel electrophoresis. Clin Diagn Lab Immunol 7:301-306.

Evans G, Wheeler CH, Corbett JM, Dunn MJ. 1997. Construction of HSC-2DPAGE: a twodimensional gel electrophoresis database of heart proteins. Electrophoresis 18:471-479.

Faleiro L, Kobayashi R, Fearnhead H, Lazebnik Y. 1997. Multiple species of CPP32 and Mch2 are the major active caspases present in apoptotic cells. EMBO J 16:2271-2281. 
Fountoulakis M, Berndt P, Boelsterli UA, Crameri F, Winter M, Albertini S, Suter L. 2000. Two-dimensional database of mouse liver proteins: changes in hepatic protein levels following treatment with acetaminophen or its nontoxic regioisomer 3-acetamidophenol. Electrophoresis 21:2148-2161.

Franzen B, Linder S, Alaiya AA, Eriksson E, Uruy K, Hirano T, Okuzawa K, Auer G. 1996. Analysis of polypeptide expression in benign and malignant human breast lesions: downregulation of cytokeratins. Br J Cancer 74:1632-1638.

Friso G, Kaiser L, Raud J, Wikstrom L. 2001. Differential protein expression in rat trigeminal ganglia during inflammation. Proteomics 1:397-408.

Gharib TG, Chen G, Wang H, Huang CC, Prescott MS, Shedden K, Misek DE, Thomas DG, Giordano TJ, Taylor JM, Kardia S, Yee J, Orringer MB, Hanash S, Beer DG. 2002. Proteomic analysis of cytokeratin isoforms uncovers association with survival in lung adenocarcinoma. Neoplasia 4:440-448.

Gianazza E, Eberini I, Villa P, Fratelli M, Pinna C, Wait R, Gemeiner M, Miller I. 2002. Monitoring the effects of drug treatment in rat models of disease by serum protein analysis. J Chromatogr B Analyt Technol Biomed Life Sci 771:107-130.

Graves PR, Haystead TA. 2002. Molecular biologist's guide to proteomics. Microbiol Mol Biol Rev 66:39-63.

Graves PR, Kwiek JJ, Fadden P, Ray R, Hardeman K, Coley AM, Foley M, Haystead TA. 2002. Discovery of novel targets of quinoline drugs in the human purine binding proteome. Mol Pharmacol 62:1364-1372.

Greenbaum DC, Baruch A, Grainger M, Bozdech Z, Medzihradszky KF, Engel J, DeRisi J, Holder AA, Bogyo M. 2002. A role for the protease falcipain 1 in host cell invasion by the human malaria parasite. Science 298:2002-2006.

Gromova I, Gromov P, Wolf H, Celis JE. 1998. Protein abundancy and mRNA levels of the adipocyte-type fatty acid binding protein correlate in non-invasive and invasive bladder transitional cell carcinomas. Int J Oncol 13:379-383.

Gururaja TL, Li W, Payan DG, Anderson DC. 2003. Utility of peptide-protein affinity complexes in proteomics: identification of interaction partners of a tumor suppressor peptide. J Pept Res 61:163-176.

Gygi SP, Rist B, Gerber SA, Turecek F, Gelb MH, Aebersold R. 1999. Quantitative analysis of complex protein mixtures using isotope-coded affinity tags. Nat Biotechnol 17:994-999.

Ha GH, Lee SU, Kang DG, Ha NY, Kim SH, Kim J, Bae JM, Kim JW, Lee CW. 2002. Proteome analysis of human stomach tissue: separation of soluble proteins by twodimensional polyacrylamide gel electrophoresis and identification by mass spectrometry. Electrophoresis 23:2513-2524.

Haas G, Karaali G, Ebermayer K, Metzger WG, Lamer S, Zimny-Arndt U, Diescher S, Goebel UB, Vogt K, Roznowski AB, Wiedenmann BJ, Meyer TF, Aebischer T, Jungblut PR. 2002. Immunoproteomics of Helicobacter pylori infection and relation to gastric disease. Proteomics 2:313-324. 
Hanash S, Brichory F, Beer D. 2001. A proteomic approach to the identification of lung cancer markers. Dis Markers 17:295-300.

Hanash SM. 2001. Global profiling of gene expression in cancer using genomics and proteomics. Curr Opin Mol Ther 3:538-545.

Hanash SM, Madoz-Gurpide J, Misek DE. 2002. Identification of novel targets for cancer therapy using expression proteomics. Leukemia 16:478-485.

He QY, Yip TT, Li M, Chiu JF. 2003a. Proteomic analyses of arsenic-induced cell transformation with SELDI-TOF ProteinChip(R) technology. J Cell Biochem 88:1-8.

He QY, Lau GKK, Zhou Y, Yuen ST, Lin MC, Kung HF, Chiu JF. 2003b. Serum biomarkers of hepatitis B virus infected liver inflammation: A proteomic study. Proteomics 3:in press.

Heegaard NH, Larsen MR, Muncrief T, Wiik A, Roepstorff P. 2000. Heterogeneous nuclear ribonucleoproteins $\mathrm{C} 1 / \mathrm{C} 2$ identified as autoantigens by biochemical and mass spectrometric methods. Arthritis Res 2:407-414.

Heinke MY, Wheeler CH, Chang D, Einstein R, Drake-Holland A, Dunn MJ, dos Remedios CG. 1998. Protein changes observed in pacing-induced heart failure using two-dimensional electrophoresis. Electrophoresis 19:2021-2030.

Heinke MY, Wheeler CH, Yan JX, Amin V, Chang D, Einstein R, Dunn MJ, dos Remedios CG. 1999. Changes in myocardial protein expression in pacing-induced canine heart failure. Electrophoresis 20:2086-2093.

Hellmold H, Nilsson CB, Schuppe-Koistinen I, Kenne K, Warngard L. 2002. Identification of end points relevant to detection of potentially adverse drug reactions. Toxicol Lett 127:239243.

Hendrickson RC, Douglass JF, Reynolds LD, McNeill PD, Carter D, Reed SG, Houghton RL. 2000. Mass spectrometric identification of mtb81, a novel serological marker for tuberculosis. J Clin Microbiol 38:2354-2361.

Herman EH, Zhang J, Rifai N, Lipshultz SE, Hasinoff BB, Chadwick DP, Knapton A, Chai J, Ferrans VJ. 2001. The use of serum levels of cardiac troponin T to compare the protective activity of dexrazoxane against doxorubicin- and mitoxantrone-induced cardiotoxicity. Cancer Chemother Pharmacol 48:297-304.

Hoffmann P, Ji H, Moritz RL, Connolly LM, Frecklington DF, Layton MJ, Eddes JS, Simpson RJ. 2001. Continuous free-flow electrophoresis separation of cytosolic proteins from the human colon carcinoma cell line LIM 1215: a non two-dimensional gel electrophoresis-based proteome analysis strategy. Proteomics 1:807-818.

Hondermarck H, Vercoutter-Edouart AS, Revillion F, Lemoine J, Yazidi-Belkoura I, Nurcombe V, Peyrat JP. 2001. Proteomics of breast cancer for marker discovery and signal pathway profiling. Proteomics 1:1216-1232.

Hueber W, Utz PJ, Steinman L, Robinson WH. 2002. Autoantibody profiling for the study and treatment of autoimmune disease. Arthritis Res 4:290-295. 
Jager D, Jungblut PR, Muller-Werdan U. 2002. Separation and identification of human heart proteins. J Chromatogr B Analyt Technol Biomed Life Sci 771:131-153.

Jeffery DA, Bogyo M. 2003. Chemical proteomics and its application to drug discovery. Curr Opin Biotechnol 14:87-95.

Jessani N, Liu Y, Humphrey M, Cravatt BF. 2002. Enzyme activity profiles of the secreted and membrane proteome that depict cancer cell invasiveness. Proc Natl Acad Sci U S A 99:10335-10340.

Jiang L, Tsubakihara M, Heinke MY, Yao M, Dunn MJ, Phillips W, dos Remedios CG, Nosworthy NJ. 2001. Heart failure and apoptosis: electrophoretic methods support data from micro- and macro-arrays. A critical review of genomics and proteomics. Proteomics 1:1481-1488.

Jones MB, Krutzsch H, Shu H, Zhao Y, Liotta LA, Kohn EC, Petricoin EF, III. 2002. Proteomic analysis and identification of new biomarkers and therapeutic targets for invasive ovarian cancer. Proteomics 2:76-84.

Jr GW, Cazares LH, Leung SM, Nasim S, Adam BL, Yip TT, Schellhammer PF, Gong L, Vlahou A. 1999. Proteinchip(R) surface enhanced laser desorption/ionization (SELDI) mass spectrometry: a novel protein biochip technology for detection of prostate cancer biomarkers in complex protein mixtures. Prostate Cancer Prostatic Dis 2:264-276.

Kanamoto T, Hellman U, Heldin CH, Souchelnytskyi S. 2002. Functional proteomics of transforming growth factor-beta1-stimulated Mv1Lu epithelial cells: Rad51 as a target of TGFbeta1-dependent regulation of DNA repair. EMBO J 21:1219-1230.

Keesee SK, Meneghini MD, Szaro RP, Wu YJ. 1994. Nuclear matrix proteins in human colon cancer. Proc Natl Acad Sci U S A 91:1913-1916.

Kennedy S. 2002. The role of proteomics in toxicology: identification of biomarkers of toxicity by protein expression analysis. Biomarkers 7:269-290.

Kidd D, Liu Y, Cravatt BF. 2001. Profiling serine hydrolase activities in complex proteomes. Biochemistry 40:4005-4015.

Klade CS, Voss T, Krystek E, Ahorn H, Zatloukal K, Pummer K, Adolf GR. 2001. Identification of tumor antigens in renal cell carcinoma by serological proteome analysis. Proteomics 1:890-898.

Kovarova H, Halada P, Man P, Dzubak P, Hajduch M. 2002. Application of Proteomics in the Search for Novel Proteins Associated with the Anti-cancer Effect of the Synthetic Cyclin-dependent Kinases Inhibitor, Bohemine. Technol Cancer Res Treat 1:247-256.

Krieg RC, Paweletz CP, Liotta LA, Petricoin EF, III. 2002. Clinical proteomics for cancer biomarker discovery and therapeutic targeting. Technol Cancer Res Treat 1:263-272.

Kuerer HM, Goldknopf IL, Fritsche H, Krishnamurthy S, Sheta EA, Hunt KK. 2002. Identification of distinct protein expression patterns in bilateral matched pair breast ductal fluid specimens from women with unilateral invasive breast carcinoma. High-throughput biomarker discovery. Cancer 95:2276-2282. 
Labugger R, McDonough JL, Neverova I, Van Eyk JE. 2002. Solubilization, twodimensional separation and detection of the cardiac myofilament protein troponin $T$. Proteomics 2:673-678.

Lakshmanan Y, Subong EN, Partin AW. 1998. Differential nuclear matrix protein expression in prostate cancers: correlation with pathologic stage. J Urol 159:1354-1358.

Le Naour F, Brichory F, Misek DE, Brechot C, Hanash SM, Beretta L. 2002. A distinct repertoire of autoantibodies in hepatocellular carcinoma identified by proteomic analysis. Mol Cell Proteomics 1:197-203.

Le Naour F, Misek DE, Krause MC, Deneux L, Giordano TJ, Scholl S, Hanash SM. 2001. Proteomics-based identification of RS/DJ-1 as a novel circulating tumor antigen in breast cancer. Clin Cancer Res 7:3328-3335.

Lewis TS, Hunt JB, Aveline LD, Jonscher KR, Louie DF, Yeh JM, Nahreini TS, Resing KA, Ahn NG. 2000. Identification of novel MAP kinase pathway signaling targets by functional proteomics and mass spectrometry. Mol Cell 6:1343-1354.

Li J, Zhang Z, Rosenzweig J, Wang YY, Chan DW. 2002. Proteomics and bioinformatics approaches for identification of serum biomarkers to detect breast cancer. Clin Chem 48:1296-1304.

Li XP, Pleissner KP, Scheler C, Regitz-Zagrosek V, Salnikow J, Jungblut PR. 1999. A twodimensional electrophoresis database of rat heart proteins. Electrophoresis 20:891-897.

Liang RC, Neo JC, Ling LS, San TG, Keong ST, Chung MC. 2002. Proteome database of hepatocellular carcinoma. J Chromatogr B Analyt Technol Biomed Life Sci 771:303-328.

Lichtenfels R, Kellner R, Bukur J, Beck J, Brenner W, Ackermann A, Seliger B. 2002. Heat shock protein expression and anti-heat shock protein reactivity in renal cell carcinoma. Proteomics 2:561-570.

Lim SO, Park S-J, Kim W, Park SG, Kim HJ, Kim YI, Sohn TS, Noh JH, Jung G. 2002. Proteome analysis of hepatocellular carcinoma. Biochem Biophys Res Commun 291:10311037.

Lind C, Gerdes R, Hamnell Y, Schuppe-Koistinen I, von Lowenhielm HB, Holmgren A, Cotgreave IA. 2002. Identification of S-glutathionylated cellular proteins during oxidative stress and constitutive metabolism by affinity purification and proteomic analysis. Arch Biochem Biophys 406:229-240.

Liotta LA, Petricoin EF, III, Ardekani AM, Hitt BA, Levine PJ, Fusaro VA, Steinberg SM, Mills GB, Simone C, Fishman DA, Kohn EC. 2003. General keynote: proteomic patterns in sera serve as biomarkers of ovarian cancer. Gynecol Oncol 88:S25-S28.

Luftner D, Possinger K. 2002. Nuclear matrix proteins as biomarkers for breast cancer. Expert Rev Mol Diagn 2:23-31.

Macdonald N, Chevalier S, Tonge R, Davison M, Rowlinson R, Young J, Rayner S, Roberts R. 2001. Quantitative proteomic analysis of mouse liver response to the peroxisome proliferator diethylhexylphthalate (DEHP). Arch Toxicol 75:415-424. 
Macri J, Rapundalo ST. 2001. Application of proteomics to the study of cardiovascular biology. Trends Cardiovasc Med 11:66-75.

Madoz-Gurpide J, Wang H, Misek DE, Brichory F, Hanash SM. 2001. Protein based microarrays: a tool for probing the proteome of cancer cells and tissues. Proteomics 1:12791287.

Maguire PB, Wynne KJ, Harney DF, O'Donoghue NM, Stephens G, Fitzgerald DJ. 2002. Identification of the phosphotyrosine proteome from thrombin activated platelets. Proteomics 2:642-648.

Man WJ, White IR, Bryant D, Bugelski P, Camilleri P, Cutler P, Heald G, Lord PG, Wood J, Kramer K. 2002. Protein expression analysis of drug-mediated hepatotoxicity in the Sprague-Dawley rat. Proteomics 2:1577-1585.

Mannes AJ, Martin BM, Yang HY, Keller JM, Lewin S, Gaiser RR, Iadarola MJ. 2003. Cystatin C as a cerebrospinal fluid biomarker for pain in humans. Pain 102:251-256.

McCormack AL, Schieltz DM, Goode B, Yang S, Barnes G, Drubin D, Yates JR, III. 1997. Direct analysis and identification of proteins in mixtures by LC/MS/MS and database searching at the low-femtomole level. Anal Chem 69:767-776.

McDonough JL, Neverova I, Van Eyk JE. 2002. Proteomic analysis of human biopsy samples by single two-dimensional electrophoresis: Coomassie, silver, mass spectrometry, and Western blotting. Proteomics 2:978-987.

Meister W. 2002. Pharmacogenomics/pharmacoproteomics Europe. Pharmacogenomics 3:449-452.

Mitsiades N, Mitsiades CS, Richardson PG, Poulaki V, Tai YT, Chauhan D, Fanourakis G, Gu X, Bailey C, Joseph M, Libermann TA, Schlossman R, Munshi NC, Hideshima T, Anderson KC. 2003. The proteasome inhibitor PS-341 potentiates sensitivity of multiple myeloma cells to conventional chemotherapeutic agents: therapeutic applications. Blood 101:2377-2380.

Muller EC, Thiede B, Zimny-Arndt U, Scheler C, Prehm J, Muller-Werdan U, WittmannLiebold B, Otto A, Jungblut P. 1996. High-performance human myocardial twodimensional electrophoresis database: edition 1996. Electrophoresis 17:1700-1712.

Naour FL, Brichory F, Beretta L, Hanash SM. 2002. Identification of tumor-associated antigens using proteomics. Technol Cancer Res Treat 1:257-262.

Neverova I, Van Eyk JE. 2002. Application of reversed phase high performance liquid chromatography for subproteomic analysis of cardiac muscle. Proteomics 2:22-31.

Newsholme SJ, Maleeff BF, Steiner S, Anderson NL, Schwartz LW. 2000. Two-dimensional electrophoresis of liver proteins: characterization of a drug-induced hepatomegaly in rats. Electrophoresis 21:2122-2128.

O'Neill EE, Brock CJ, von Kriegsheim AF, Pearce AC, Dwek RA, Watson SP, Hebestreit HF. 2002. Towards complete analysis of the platelet proteome. Proteomics 2:288-305. 
Oh JM, Brichory F, Puravs E, Kuick R, Wood C, Rouillard JM, Tra J, Kardia S, Beer D, Hanash S. 2001. A database of protein expression in lung cancer. Proteomics 1:1303-1319.

Ornstein DK, Gillespie JW, Paweletz CP, Duray PH, Herring J, Vocke CD, Topalian SL, Bostwick DG, Linehan WM, Petricoin EF, III, Emmert-Buck MR. 2000. Proteomic analysis of laser capture microdissected human prostate cancer and in vitro prostate cell lines. Electrophoresis 21:2235-2242.

Ostergaard M, Rasmussen HH, Nielsen HV, Vorum H, Orntoft TF, Wolf H, Celis JE. 1997. Proteome profiling of bladder squamous cell carcinomas: identification of markers that define their degree of differentiation. Cancer Res 57:4111-4117.

Ostergaard M, Wolf H, Orntoft TF, Celis JE. 1999. Psoriasin (S100A7): a putative urinary marker for the follow-up of patients with bladder squamous cell carcinomas. Electrophoresis 20:349-354.

Otto A, Thiede B, Muller EC, Scheler C, Wittmann-Liebold B, Jungblut P. 1996. Identification of human myocardial proteins separated by two-dimensional electrophoresis using an effective sample preparation for mass spectrometry. Electrophoresis 17:1643-1650.

Owens J. 2001. Topological proteomics: a new approach to drug discovery. Drug Discov Today 6:1081-1082.

Pankuweit S, Portig I, Lottspeich F, Maisch B. 1997. Autoantibodies in sera of patients with myocarditis: characterization of the corresponding proteins by isoelectric focusing and Nterminal sequence analysis. J Mol Cell Cardiol 29:77-84.

Park K-S, Cho SY, Kim H, Paik Y-K. 2002. Proteomic alterations of the variants of human aldehyde dehydrogenase isozymes correlate with hepatocellular carcinoma. Int $\mathrm{J}$ Cancer 97:261-265.

Patel V, Leethanakul C, Gutkind JS. 2001. New approaches to the understanding of the molecular basis of oral cancer. Crit Rev Oral Biol Med 12:55-63.

Patterson S. 2002. Selecting targets for therapeutic validation through differential protein expression using chromatography-mass spectrometry. Bioinformatics 18 Suppl 2:S181.

Paweletz CP, Liotta LA, Petricoin III EF. 2001a. New technologies for biomarker analysis of prostate cancer progression: laser capture microdissection and tissue proteomics. Urology 57:160-163.

Paweletz CP, Trock B, Pennanen M, Tsangaris T, Magnant C, Liotta LA, Petricoin EF, III. 2001b. Proteomic patterns of nipple aspirate fluids obtained by SELDI-TOF: potential for new biomarkers to aid in the diagnosis of breast cancer. Dis Markers 17:301-307.

Peng J, Gygi SP. 2001. Proteomics: the move to mixtures. J Mass Spectrom 36:1083-1091.

Petricoin EF, Ardekani AM, Hitt BA, Levine PJ, Fusaro VA, Steinberg SM, Mills GB, Simone C, Fishman DA, Kohn EC, Liotta LA. 2002. Use of proteomic patterns in serum to identify ovarian cancer. Lancet 359:572-577. 
Petricoin EF, III, Ornstein DK, Paweletz CP, Ardekani A, Hackett PS, Hitt BA, Velassco A, Trucco C, Wiegand L, Wood K, Simone CB, Levine PJ, Linehan WM, Emmert-Buck MR, Steinberg SM, Kohn EC, Liotta LA. 2002. Serum proteomic patterns for detection of prostate cancer. J Natl Cancer Inst 94:1576-1578.

Pleissner KP, Regitz-Zagrosek V, Krudewagen B, Trenkner J, Hocher B, Fleck E. 1998. Effects of renovascular hypertension on myocardial protein patterns: analysis by computerassisted two-dimensional gel electrophoresis. Electrophoresis 19:2043-2050.

Pleissner KP, Sander S, Oswald H, Regitz-Zagrosek V, Fleck E. 1996. The construction of the World Wide Web-accessible myocardial two-dimensional gel electrophoresis protein database "HEART-2DPAGE": a practical approach. Electrophoresis 17:1386-1392.

Pleissner KP, Soding P, Sander S, Oswald H, Neuss M, Regitz-Zagrosek V, Fleck E. 1997. Dilated cardiomyopathy-associated proteins and their presentation in a WWW-accessible two-dimensional gel protein database. Electrophoresis 18:802-808.

Pohlner K, Portig I, Pankuweit S, Lottspeich F, Maisch B. 1997. Identification of mitochondrial antigens recognized by antibodies in sera of patients with idiopathic dilated cardiomyopathy by two-dimensional gel electrophoresis and protein sequencing. Am J Cardiol 80:1040-1045.

Poirier F, Pontet M, Labas V, Le Caer JP, Sghiouar-Imam N, Raphael M, Caron M, JoubertCaron R. 2001. Two-dimensional database of a Burkitt lymphoma cell line (DG 75) proteins: protein pattern changes following treatment with 5'-azycytidine. Electrophoresis 22:1867-1877.

Prasannan L, Misek DE, Hinderer R, Michon J, Geiger JD, Hanash SM. 2000. Identification of beta-tubulin isoforms as tumor antigens in neuroblastoma. Clin Cancer Res 6:3949-3956.

Qian Y, Sensibar JA, Zelner DJ, Schaeffer AJ, Finlay JA, Rittenhouse HG, Lee C. 1997. Two-dimensional gel electrophoresis detects prostate-specific antigen-alpha1antichymotrypsin complex in serum but not in prostatic fluid. Clin Chem 43:352-359.

Qu Y, Adam BL, Yasui Y, Ward MD, Cazares LH, Schellhammer PF, Feng Z, Semmes OJ, Wright GL, Jr. 2002. Boosted decision tree analysis of surface-enhanced laser desorption/ionization mass spectral serum profiles discriminates prostate cancer from noncancer patients. Clin Chem 48:1835-1843.

Randic M, Basak SC. 2002. A comparative study of proteomics maps using graph theoretical biodescriptors. J Chem Inf Comput Sci 42:983-992.

Rasmussen HH, Orntoft TF, Wolf H, Celis JE. 1996. Towards a comprehensive database of proteins from the urine of patients with bladder cancer. J Urol 155:2113-2119.

Rubenwolf S, Niewohner J, Meyer E, Petit-Frere C, Rudert F, Hoffmann PR, Ilag LL. 2002. Functional proteomics using chromophore-assisted laser inactivation. Proteomics 2:241246.

Ruepp SU, Tonge RP, Shaw J, Wallis N, Pognan F. 2002. Genomics and proteomics analysis of acetaminophen toxicity in mouse liver. Toxicol Sci 65:135-150. 
Sanchez JC, Converset V, Nolan A, Schmid G, Wang S, Heller M, Sennitt MV, Hochstrasser DF, Cawthorne MA. 2002. Effect of rosiglitazone on the differential expression of diabetesassociated proteins in pancreatic islets of C57Bl/6 lep/lep mice. Mol Cell Proteomics 1:509516.

Sarto C, Frutiger S, Cappellano F, Sanchez JC, Doro G, Catanzaro F, Hughes GJ, Hochstrasser DF, Mocarelli P. 1999. Modified expression of plasma glutathione peroxidase and manganese superoxide dismutase in human renal cell carcinoma. Electrophoresis 20:3458-3466.

Saulot V, Vittecoq O, Charlionet R, Fardellone P, Lange C, Marvin L, Machour N, Le L, X, Gilbert D, Tron F. 2002. Presence of autoantibodies to the glycolytic enzyme alpha-enolase in sera from patients with early rheumatoid arthritis. Arthritis Rheum 46:1196-1201.

Scheler C, Li XP, Salnikow J, Dunn MJ, Jungblut PR. 1999. Comparison of two-dimensional electrophoresis patterns of heat shock protein Hsp27 species in normal and cardiomyopathic hearts. Electrophoresis 20:3623-3628.

Scheler C, Muller EC, Stahl J, Muller-Werdan U, Salnikow J, Jungblut P. 1997a. Identification and characterization of heat shock protein 27 protein species in human myocardial two-dimensional electrophoresis patterns. Electrophoresis 18:2823-2831.

Scheler C, Muller EC, Stahl J, Muller-Werdan U, Salnikow J, Jungblut P. 1997b. Identification and characterization of heat shock protein 27 protein species in human myocardial two-dimensional electrophoresis patterns. Electrophoresis 18:2823-2831.

Schwertz H, Langin T, Platsch H, Richert J, Bomm S, Schmidt M, Hillen H, Blaschke G, Meyer J, Darius H, Buerke M. 2002. Two-dimensional analysis of myocardial protein expression following myocardial ischemia and reperfusion in rabbits. Proteomics 2:988995.

Seow TK, Liang RC, Leow CK, Chung MC. 2001. Hepatocellular carcinoma: from beside to proteomics. Proteomics 1:1249-1263.

Seow TK, Ong SE, Liang RC, Ren EC, Chan L, Ou K, Chung MC. 2000. Two-dimensional electrophoresis map of the human hepatocellular carcinoma cell line, HCC-M, and identification of the separated proteins by mass spectrometry. Electrophoresis 21:17871813.

Shalhoub P, Kern S, Girard S, Beretta L. 2001. Proteomic-based approach for the identification of tumor markers associated with hepatocellular carcinoma. Dis Markers 17:217-223.

Simpson RJ, Connolly LM, Eddes JS, Pereira JJ, Moritz RL, Reid GE. 2000. Proteomic analysis of the human colon carcinoma cell line (LIM 1215): development of a membrane protein database. Electrophoresis 21:1707-1732.

Singh VK, Jayaswal RK, Wilkinson BJ. 2001. Cell wall-active antibiotic induced proteins of Staphylococcus aureus identified using a proteomic approach. FEMS Microbiol Lett 199:79-84. 
Sinha P, Hutter G, Kottgen E, Dietel M, Schadendorf D, Lage H. 1998. Increased expression of annexin I and thioredoxin detected by two-dimensional gel electrophoresis of drug resistant human stomach cancer cells. J Biochem Biophys Methods 37:105-116.

Sinha P, Poland J, Schnolzer M, Celis JE, Lage H. 2001. Characterization of the differential protein expression associated with thermoresistance in human gastric carcinoma cell lines. Electrophoresis 22:2990-3000.

Sironi L, Tremoli E, Miller I, Guerrini U, Calvio AM, Eberini I, Gemeiner M, Asdente M, Paoletti R, Gianazza E. 2001. Acute-phase proteins before cerebral ischemia in stroke-prone rats: identification by proteomics. Stroke 32:753-760.

Smith MA, Bains SK, Betts JC, Choy EH, Zanders ED. 2001. Use of two-dimensional gel electrophoresis to measure changes in synovial fluid proteins from patients with rheumatoid arthritis treated with antibody to CD4. Clin Diagn Lab Immunol 8:105-111.

Spencer DI, Robson L, Purdy D, Whitelegg NR, Michael NP, Bhatia J, Sharma SK, Rees AR, Minton NP, Begent RH, Chester KA. 2002. A strategy for mapping and neutralizing conformational immunogenic sites on protein therapeutics. Proteomics 2:271-279.

Srisomsap C, Subhasitanont P, Otto A, Mueller EC, Punyarit P, Wittmann-Liebold B, Svasti J. 2002. Detection of cathepsin B up-regulation in neoplastic thyroid tissues by proteomic analysis. Proteomics 2:706-712.

Stancato LF, Petricoin EF, III. 2001. Fingerprinting of signal transduction pathways using a combination of anti-phosphotyrosine immunoprecipitations and two-dimensional polyacrylamide gel electrophoresis. Electrophoresis 22:2120-2124.

Steel LF, Mattu TS, Mehta A, Hebestreit H, Dwek R, Evans AA, London WT, Block T. 2001. A proteomic approach for the discovery of early detection markers of hepatocellular carcinoma. Dis Markers 17:179-189.

Steiner S, Anderson NL. 2000. Expression profiling in toxicology--potentials and limitations. Toxicol Lett 112-113:467-471.

Steiner S, Gatlin CL, Lennon JJ, McGrath AM, Aponte AM, Makusky AJ, Rohrs MC, Anderson NL. 2000. Proteomics to display lovastatin-induced protein and pathway regulation in rat liver. Electrophoresis 21:2129-2137.

Storm SM, Khawaja XZ. 1999. Probing for drug-induced multiplex signal transduction pathways using high resolution two-dimensional gel electrophoresis: application to betaadrenoceptor stimulation in the rat C6 glioma cell. Brain Res Mol Brain Res 71:50-60.

Stulik J, Hernychova L, Porkertova S, Knizek J, Macela A, Bures J, Jandik P, Langridge JI, Jungblut PR. 2001. Proteome study of colorectal carcinogenesis. Electrophoresis 22:30193025.

Tan S, Seow TK, Liang RC, Koh S, Lee CP, Chung MC, Hooi SC. 2002. Proteome analysis of butyrate-treated human colon cancer cells (HT-29). Int J Cancer 98:523-531.

Tang H, Peng T, Wong-Staal F. 2002. Novel technologies for studying virus-host interaction and discovering new drug targets for HCV and HIV. Curr Opin Pharmacol 2:541-547. 
Taurin S, Seyrantepe V, Orlov SN, Tremblay TL, Thibault P, Bennett MR, Hamet P, Pshezhetsky AV. 2002. Proteome analysis and functional expression identify mortalin as an antiapoptotic gene induced by elevation of $[\mathrm{Na}+] \mathrm{i} /[\mathrm{K}+] \mathrm{i}$ ratio in cultured vascular smooth muscle cells. Circ Res 91:915-922.

Toledo-Sherman LM, Chen D. 2002. High-throughput virtual screening for drug discovery in parallel. Curr Opin Drug Discov Devel 5:414-421.

Tomlinson AJ, Hincapie M, Morris GE, Chicz RM. 2002. Global proteome analysis of a human gastric carcinoma. Electrophoresis 23:3233-3240.

Tontsch D, Pankuweit S, Maisch B. 2000. Autoantibodies in the sera of patients with rheumatic heart disease: characterization of myocardial antigens by two-dimensional immunoblotting and N-terminal sequence analysis. Clin Exp Immunol 121:270-274.

Van Eyk JE. 2001. Proteomics: unraveling the complexity of heart disease and striving to change cardiology. Curr Opin Mol Ther 3:546-553.

VerBerkmoes NC, Bundy JL, Hauser L, Asano KG, Razumovskaya J, Larimer F, Hettich RL, Stephenson JL, Jr. 2002. Integrating 'top-down" and "bottom-up" mass spectrometric approaches for proteomic analysis of Shewanella oneidensis. J Proteome Res 1:239-252.

Vlahou A, Schellhammer PF, Mendrinos S, Patel K, Kondylis FI, Gong L, Nasim S, Wright JG, Jr. 2001. Development of a novel proteomic approach for the detection of transitional cell carcinoma of the bladder in urine. Am J Pathol 158:1491-1502.

Voss T, Ahorn H, Haberl P, Dohner H, Wilgenbus K. 2001. Correlation of clinical data with proteomics profiles in 24 patients with B-cell chronic lymphocytic leukemia. Int J Cancer 91:180-186.

Wan J, Wang J, Cheng H, Yu Y, Xing G, Oiu Z, Qian X, He F. 2001. Proteomic analysis of apoptosis initiation induced by all-trans retinoic acid in human acute promyelocytic leukemia cells. Electrophoresis 22:3026-3037.

Wang H, Hanash SM. 2002. Contributions of proteome profiling to the molecular analysis of cancer. Technol Cancer Res Treat 1:237-246.

Wang YY, Khoo KH, Chen ST, Lin CC, Wong CH, Lin CH. 2002. Studies on the immunomodulating and antitumor activities of Ganoderma lucidum (Reishi) polysaccharides: functional and proteomic analyses of a fucose-containing glycoprotein fraction responsible for the activities. Bioorg Med Chem 10:1057-1062.

Wasinger VC, Cordwell SJ, Cerpa-Poljak A, Yan JX, Gooley AA, Wilkins MR, Duncan MW, Harris R, Williams KL, Humphery-Smith I. 1995. Progress with gene-product mapping of the Mollicutes: Mycoplasma genitalium. Electrophoresis 16:1090-1094.

Weekes J, Watson RR, Dunn MJ. 2003. Murine retrovirus infection and the effect of chronic alcohol consumption: proteomic analysis of cardiac protein expression. Alcohol Alcohol 38:103-108. 
Weekes J, Wheeler CH, Yan JX, Weil J, Eschenhagen T, Scholtysik G, Dunn MJ. 1999. Bovine dilated cardiomyopathy: proteomic analysis of an animal model of human dilated cardiomyopathy. Electrophoresis 20:898-906.

Wellmann A, Wollscheid V, Lu H, Ma ZL, Albers P, Schutze K, Rohde V, Behrens P, Dreschers S, Ko Y, Wernert N. 2002. Analysis of microdissected prostate tissue with ProteinChip arrays--a way to new insights into carcinogenesis and to diagnostic tools. Int $\mathrm{J}$ Mol Med 9:341-347.

White IR, Man WJ, Bryant D, Bugelski P, Camilleri P, Cutler P, Hayes W, Holbrook JD, Kramer K, Lord PG, Wood J. 2003. Protein expression changes in the Sprague Dawley rat liver proteome following administration of peroxisome proliferator activated receptor alpha and gamma ligands. Proteomics 3:505-512.

Wilkins MR, Sanchez JC, Gooley AA, Appel RD, Humphery-Smith I, Hochstrasser DF, Williams KL. 1996. Progress with proteome projects: why all proteins expressed by a genome should be identified and how to do it. Biotechnol Genet Eng Rev 13:19-50.

Wulfkuhle JD, McLean KC, Paweletz CP, Sgroi DC, Trock BJ, Steeg PS, Petricoin EF, III. 2001. New approaches to proteomic analysis of breast cancer. Proteomics 1:1205-1215.

Wulfkuhle JD, Sgroi DC, Krutzsch H, McLean K, McGarvey K, Knowlton M, Chen S, Shu H, Sahin A, Kurek R, Wallwiener D, Merino MJ, Petricoin EF, III, Zhao Y, Steeg PS. 2002. Proteomics of human breast ductal carcinoma in situ. Cancer Res 62:6740-6749.

Yates JR. 1996. Protein structure analysis by mass spectrometry. Methods Enzymol 271:351377.

Yates JR, III. 1998. Mass spectrometry and the age of the proteome. J Mass Spectrom 33:119.

Yates JR, III, Carmack E, Hays L, Link AJ, Eng JK. 1999. Automated protein identification using microcolumn liquid chromatography-tandem mass spectrometry. Methods Mol Biol 112:553-569.

Yates JR, III, McCormack AL, Schieltz D, Carmack E, Link A. 1997. Direct analysis of protein mixtures by tandem mass spectrometry. J Protein Chem 16:495-497.

Yip TT, Lomas L. 2002. SELDI ProteinChip((R)) Array in Oncoproteomic Research. Technol Cancer Res Treat 1:273-280.

Zhou G, Li H, DeCamp D, Chen S, Shu H, Gong Y, Flaig M, Gillespie JW, Hu N, Taylor PR, Emmert-Buck MR, Liotta LA, Petricoin EF, III, Zhao Y. 2002. 2D differential in-gel electrophoresis for the identification of esophageal scans cell cancer-specific protein markers. Mol Cell Proteomics 1:117-124. 